\title{
SCADidoc
}

International Journal of Dairy Processing \& Research (IJDPR)

\section{Effects of Refrigeration, Deep Freezing-Spray Drying and Pasteurization on IgG Bovine Colostrum Preservation}

S.Bhavani Ramya ${ }^{1}$, D.Ramasamy ${ }^{2}$, Dhineshkumar. $\mathrm{V}^{3 *}$

${ }^{1}$ M.Tech scholar, College of Food and Dairy Technology, Tanuvas, India.

${ }^{2}$ Professor and Head, Dept.of.Food science and Technology, CFDT, Tanuvas, India.

${ }^{3} \mathrm{Ph} . \mathrm{D}$ Research Scholar, College of Food and Dairy Technology, Tanuvas, India.

Abstract

The aim of this paper was to evaluate the effects of refrigeration, several different methods of thawing, and pasteurization on the concentration of $\operatorname{IgG}$ in bovine colostrum. Four different experiments were designed to analyse these effects. In the first of these, 50 samples of bovine colostrum were stored in a cold-storage room at a temperature of $4^{0} \mathrm{C}$ for a 3 -month period. No statistically significant effects were observed within this time, although there was a reduction in $\operatorname{IgG}$ concentrations (51.05and $25.11 \mathrm{mg} / \mathrm{ml} \mathrm{IgG} \mathrm{at} \mathrm{day} 0$ and 91 , respectively). In the second experiment, 20 samples of bovine colostrum were frozen and subsequently thawed using four different methods: spray drying $\left(60^{\circ} \mathrm{C}\right)$, refrigeration $\left(4^{0} \mathrm{C}\right)$, deep freezing $\left(-20^{\circ} \mathrm{C}\right)$ and freeze drying $\left(55^{\circ} \mathrm{C}\right)$. The process was carried out seven times for each of the four methods. The method of thawing did not affect the colostrum IgG concentration. However, the repetition of freezing and thawing tended to reduce IgG concentrations; albeit to no significant degree (15.50 and $10.73 \mathrm{mg} / \mathrm{ml} \mathrm{IgG} \mathrm{at} \mathrm{cycle} 0$ and 7 , respectively). In the third experiment, 30 bovine colostrum samples were used and a reduction of approximately $35 \%$ of $\operatorname{IgG}$ concentration after pasteurization was observed. Refrigeration, freezing and pasteurization are suitable methods for conserving bovine colostrum.

Keywords: Colostrum; Goat; Refrigeration; Thawing; Pasteurization.

\section{Introduction}

Colostrum is the nutrient rich, first secretion produced by mammals within 24 to 72 hours after parturition. It is a mixture of lacteal secretions and constituents of blood serum, notable immunoglobulin and serum proteins that accumulate in mammary gland during prepartum dry period which can be harvested immediately after parturition [6]. Bovine Colostrum is the first milk secreted at the time of parturition which lasts for 2- 4 days which contains more lactalbumin and protein and rich in antibodies that confer passive immunity to the newborn. The colostrum can either be fresh (obtained directly from the mother) or preserved (either refrigerated or frozen). The latter system is of particular inter-est in areas where diseases such as CAEV are present, since colostrum is one of the direct means of trans-mission[7]. Pasteurization can play a vital role in preventing such transmission. Several authors have confirmed this fact; Adams et al. (1983) demonstrated the inactivation of encephalitis arthritis virus in goats after a $60 \mathrm{~min}$ pasteurization treatment at $56^{\circ} \mathrm{C}$, while Moore et al. (1996) successfully in-activated the BIV virus with a 30 min pasteurization treatment at $47^{\circ} \mathrm{C}$, and Meylan et al. (1996) observed a reduction in levels of Mycobacterium Para tuberculosis in bovine colostrum after pasteurization $\left(62^{\circ} \mathrm{C}\right.$ for $\left.30 \mathrm{~min}\right)$.

With respect to colostrum preservation methods, the most commonly cited forms are freezing [8, 16, 19], refrigeration [22], lyophilizing [10], the addition of acidifying substances [17] or sub-stances with a buffering capacity [9]. Chemical preservation methods are recommended for storage at room temperature in cases where freezing facilities are not available [6].

The objective of this research was to determine the IgG concentration of colostrum refrigerated over a long period of time, and to evaluate the effects of different methods of thawing and pasteurizing techniques on $\operatorname{Ig} G$ concentration in goat colostrum.

\section{Material and Methods}

Four different experiments were conducted. In the first, the effect of cow colostrum refrigeration time on $\mathrm{IgG}$ concentration was evaluated. The study was conducted on 25 cross bred cows in Community Cattle Care Centre of CFDT, Koduvalli.Colostrum

\footnotetext{
*Corresponding Author:

Dhineshkumar.V Ph.D

Research Scholar, College of Food and Dairy Technology, Tanuvas, India

E-mail: dhineshfpe@gmail.com
}

Received: January 29, 2016

Accepted: April 13, 2016

Published: April 26, 2016

Citation: S. Bhavani Ramya, D. Ramasamy, Dhineshkumar. V (2016) Effects of Refrigeration, Deep Freezing-Spray Drying and Pasteurization on IgG Bovine Colostrum Preservation. Int J Dairy Process Res. 3(1), 35-37. doi: http://dx.doi.org/10.19070/2379-1578-160010

Copyright: Dhineshkumar. $V^{\odot} 2016$. This is an open-access article distributed under the terms of the Creative Commons Attribution License, which permits unrestricted use, distribution and reproduction in any medium, provided the original author and source are credited. 
samples were collected for 7 days after parturition from cow.After collection, the colostrum samples were stored at $-20^{\circ} \mathrm{C}$ until further analysis.In the second experiment, the effect of the refrigeration method on $\mathrm{IgG}$ concentration was evaluated.In the first treatment, colostrum samples were filtered and packed in heat resistant laminated pouches and subsequently pasteurized for $60^{\circ} \mathrm{C}$ for 60 minutes and cooled to $5^{0 e} \mathrm{C}$, stored in refrigerator for 7 days period and analyzed. The refined sugar, banana, cocoa powder were added and filled in pouches and subsequently pasteurized at $63^{\circ} \mathrm{C}$ for 30 minutes.

In the second experiment, the effect of the freezing method on $\mathrm{IgG}$ concentration was evaluated.In the second treatment, the colostrum is filtered and packed in heat resistant laminated pouches and pasteurized for $60^{\circ} \mathrm{C}$ for 60 minutes and cooled to $5^{\circ} \mathrm{C}$, stored in deep freezer at $-20^{\circ} \mathrm{C}$.During analysis the samples were thawed in hot water for 30 minutes at $60^{\circ} \mathrm{C}$. After thawing refined sugar, banana, and cocoa powder were added and filled in another heat resistant laminated pouches and subsequently pasteurized at $63^{\circ} \mathrm{C}$ for 30 minutes. The third experiment used the sample was skimmed, pasteurized, spray dried and analyzed and stored at room temperature.

The IgG quantification was made according to Mancini et al. (1965) with some modifications. Briefly, the agar was prepared by adding 11 of glycine buffer $\mathrm{pH} 7$ (7.5 g glycine, $100 \mathrm{ml}$ EDTA $0.4 \mathrm{M}$, in distilled water, and adjusting the volume to $1 \mathrm{l}$ ) to $20 \mathrm{~g}$ of agar. This suspension was placed in a boiling water-bath and stirred until all the agar had dissolved, after which it was cooled to $60^{\circ} \mathrm{C}$. The antiserum (previously made by rabbit immunization with bovine $\operatorname{IgG}$ ) or a suitable dilution of it made in glycine buffer was heated to $55^{\circ} \mathrm{C}$, after which both solutions were mixed thoroughly, avoiding bubbling, with the aid ofa pipette preheated to $60^{\circ} \mathrm{C}$ in the water-bath. The antiserum-agar mixture was immediately poured into the petri dish with a final agar thickness of 0.3 $\mathrm{cm}$. The petri dish was sealed and stored at $4^{\circ} \mathrm{C}$ until use. Circular wells were punched in the gel, using a 3 mmbore needle. The small cylinders of gel cut out by the needle were removed by suction. Each of the wells received $10 \mu$ of antigen solution (standard curve) orblood serum. In each petri dish three wells receivedantigen solution for the preparation of the standardcurve, this was prepared according to the methodused by Catty and Raykundalia (1988).

With reference to statistical analysis, in experiment1, a one-way analysis was used to test the effect of time on IgG colostrum concentration, in experiment2, a GLM procedure was used, including number of cycle and thawing methods as fixed effects, and in experiment 3, a one-way analysis was used to test the effect of pasteurization on IgG colostrum concentration and differences between means were tested by the Tukey t-test. All analysis were performed using the SPSS (v. 10.0) statistics program.

\section{Results and Discussion}

Table 1 shows the evolution of $\operatorname{IgG}$ concentration in colostrum kept in refrigeration at $4^{\circ} \mathrm{C}$ over a 91 -day period. No significant statistical variation was observed $(\mathrm{P}=0.579)$ in this concentration during refrigeration time, although it did tend to diminish at the end of the experiment (51\%). The main reduction occurred during the first month of the test $(30 \%)$, possibly because it was during this period that the natural fermentation process of the colostrum took place. Itcan be stated that refrigeration has a clear preservation effect on $\mathrm{IgG}$ concentration in goat colostrum, as was claimed by Valenta (1982) in his work with bovine colostrum when he observed only slight variations of $\operatorname{IgG}$ colostrum concentration when this was refrigerated at -2 to $+2{ }^{\circ} \mathrm{C}$ over a 14-day period. In contrast, Mbuthia et al. (1997) observed a significant reduction in $\operatorname{IgG}$ concentration in colostrum stored at $28^{\circ} \mathrm{C}$. In conclusion, after 3 months of preservation at refrigeration temperatures of $4^{\circ} \mathrm{C}$, IgG levels diminish by $30 \%$, but the colostrum is still usable for new-born kids, although where possible it would be desirable to store colostrum for no longer than amonth after collection.

The freezing of colostrum is a well-known method of preservation. Morand-Fehr (1989) stated that immunoglobulin's present in goat colostrum remain intact for 2 years, while Bilbao et al. (2001) ascertained that the maximum freezing time for bovine colostrum is 15 years. In Table 2, the evolution of $\operatorname{IgG}$ concentrations in colostrum throughout the freezing-thawing cycles with different thawing methods can be observed. There is no statistical interaction between the two effects (cycle and thawing method), since the thawing method used shows no variation with respect to IgG concentration, although the number of times the colostrum was subsequently refrozen and thawed does have a reducing effect on IgG concentration.

The reduction of $\operatorname{IgG}$ levels after several freezing-thawing cycles is probably due to the effect of temperature changes, though on no occasion did the temperature exceed $60^{\circ} \mathrm{C}$, the temperature at which globulins begin to break up, as has been demonstrated by Anema (2000). Similar results have been obtained by Jones et al. (1987) using cattle colostrum, observing that casein, IgG and IgM concentrations were not significantly affected by microwave thawing in reference to colostrum thawed for $25 \mathrm{~min}$ in water at $45^{\circ} \mathrm{C}$. With respect to the pasteurization of colostrum, Table 2 shows how this has a negative effect on $\mathrm{IgG}$ concentration, reducing it in the first case by $50.34 \%$ and by $37.84 \%$ in the second.

The CFU was stronglyreduced by both pasteurization processes. Major significant differences between the $\operatorname{IgG}$ concentration in colostrum prior to and after pasteurization treatments was observed, while no statistically significant differences are observable between the two treatments carried out. The reduction observed in the colostrum $\operatorname{IgG}$ concentration after pasteurization is greater than that observed in the results of the research carried out on bovine colostrum by Meylan et al. (1996). Incomplete contrast to this is the work carried out by Steinbach et al. (1981) in which no reduction in $\mathrm{IgG}$ concentration was observed after the pasteurization process. This apparent discrepancy could be due to the decreased exposure time to pasteurization of the colostrum used in the analysis (30 min) in comparison with our study.

\section{Conclusion}

In conclusion, refrigeration is a good method of $\operatorname{IgG}$ preservation for goat colostrum for the first 3 months, and the methods of thawing used have less effect on $\operatorname{IgG}$ concentration than the number of times which colostrum is thawed and refrozen. Pasteurization has a negative effect on $\mathrm{IgG}$ concentration, although theeffect of the latter on the transfer of passive immunity needs 
Table 1 . IgG (mean \pm standard deviation) bovine colostrum concentration during refrigeration time

\begin{tabular}{|c|c|c|}
\hline Days & IgG $(\mathrm{mg} / \mathrm{ml})$ & $\mathbf{P}$ \\
\hline 1 & $80.1 \pm 5.08^{\mathrm{g}}$ & \\
\hline 2 & $75.4 \pm 1.13^{\mathrm{f}}$ & \\
\hline 3 & $71.3 \pm 1.5^{\mathrm{e}}$ & \multirow{2}{*}{0.579} \\
\hline 4 & $66.1 \pm 0.99^{\mathrm{d}}$ & \\
\hline 5 & $61.5 \pm 0.49^{\mathrm{c}}$ & \\
\hline 6 & $55.1 \pm 0.67^{\mathrm{b}}$ & \\
\hline 7 & $51.5 \pm 0.27^{\mathrm{a}}$ & \\
\hline
\end{tabular}

Table 2 . IgG (mean \pm standard deviation) goat colostrum concentration through freezing-thawing cycles

\begin{tabular}{|c|c|c|c|c|c|c|}
\hline \multirow{3}{*}{$\begin{array}{c}\text { Days } \\
0\end{array}$} & \multicolumn{4}{|c|}{ Treatments } & \multirow{2}{*}{\multicolumn{2}{|c|}{ Effects* }} \\
\hline & Refrigerated & Deep freezing & Spray drying & Freeze drying & & \\
\hline & $78.20 \pm 0.8$ & $70.20 \pm 1.4$ & $66.54 \pm 1.6$ & $72.28 \pm 1.2$ & \multirow{7}{*}{0.069} & \multirow{7}{*}{0.959} \\
\hline 15 & $73.10 \pm 1.7$ & $67.61 \pm 1.8$ & $62.76 \pm 0.8$ & $68.01 \pm 0.7$ & & \\
\hline 30 & $69.45 \pm 1.7$ & $61.05 \pm 1.2$ & $58.35 \pm 1.5$ & $62.45 \pm 1.7$ & & \\
\hline 45 & $64.31 \pm 2.4$ & $58.71 \pm 1.0$ & $51.51 \pm 2.1$ & $57.01 \pm 1.2$ & & \\
\hline 60 & $59.01 \pm 2.4$ & $52.21 \pm 1.4$ & $46.07 \pm 1.8$ & $52.60 \pm 0.9$ & & \\
\hline 75 & $54.50 \pm 1.7$ & $47.54 \pm 0.9$ & $40.74 \pm 1.3$ & $47.08 \pm 1.4$ & & \\
\hline 90 & $50.34 \pm 1.7$ & $42.20 \pm 0.6$ & $34.05 \pm 2.1$ & $42.25 \pm 0.8$ & & \\
\hline
\end{tabular}

to be evaluated. The recommendations of this paper are to freeze in small quantities and to refrigerate left over thawed colostrum.

\section{References}

[1]. Adams DS, Klevjer-Anderson P, Carlson JL, McGuire TC, Gorham JR (1983) Transmission and control of caprine arthritis-encephalitis virus. Am J Vet Res 44(9): 1670-1675.

[2]. Anema SG (2000) Effects of milk concentration on the irreversible thermal denaturation and disulfide aggregation of beta-lactoglobulin. J Agric Food Chem 48(9): 4168-4175.

[3]. Beerens H, Luquet FM (1987) Guide practique d' analyse microbiologique des laits et des produits laitiers. Technique et Documentation (Lavoisier), Paris. 151

[4]. Bilbao GN, Landi HG, Guarrochena V (2001) Calostro fermentado: una alternativa en la dieta l'iquida para terneros. Nuestra Cabaña 305: 18-23.

[5]. Catty D, Raykundalia C (1988) Gel immunodiffusion, immunoelectrophoresis and immunostaining methods. In: Antibodies. IRL Press, Oxford, UK. 137-167.

[6]. Foley JA, Otterby DE (1978) Availability, storage, treatment, composition and feeding value of surplus colostrum: a review. J Dairy Sci 61(8): 10331060

[7]. Guerrault P (1990) Apport de colostrum: plusieurs methodes. La Chevre 180: 30-31.

[8]. Holloway NM, Tyler JW, Lakritz J, Carlson S, Holle J (2001) Serum immunoglobulin $\mathrm{G}$ concentrations in calves fed fresh and frozen colostrum. J Am Vet Med Assoc 219(3): 357-359.

[9]. Jenny BF, Hodge SE, O’Dell GD, Ellers JE (1984) Influence of colostrum preservation and sodium bicarbonate on performance of dairy calves. J Dairy Sci 67(2): 313-318

[10]. Klobasa F, Goel MC, Werhahn E (1998) Comparison of freezing and lyophilizing for preservation of colostrum as a source of immunoglobulins for calves. J Anim Sci 76(4): 923-926.
[11]. Lakritz J, Tyler JW, Hostetler DE, Marsh AE, Weaver DM, et al. (2000) Effects of pasteurization of colostrum on subsequent serum lactoferrin concentration and neutrophil superoxide production in calves. Am J Vet Res 61(9): 1021-1025

[12]. Mancini G, Carbonara AO, Heremans JF (1965) Immunochemical quantitation of antigens by single radial immunodiffusion. Immunochemistry 2(3): 235-254

[13]. Mbuthia EW, Klobasa F, Gachuiri CK, Abate A (1997) Effect of treatment with formaldehyde and formic acid on immunoglobulin content of stored bovine colostrum. Anim Feed Sci Tech 67(4): 291-298.

[14]. Meylan M, Rings DM, Shulaw WP, Kowalski JJ, Bech-Nielsen B, et al (1996) Survival of Mycobacterium paratuberculosis and preservation of immunoglobulin $\mathrm{G}$ in bovine colostrum under experimental conditions simulating pasteurization. Am J Vet Res 57(11): 1580-1585.

[15]. Moore EC, Keil D, Coats KS (1996) Thermal inactivation of bovine immunodeficiency virus. Appl Environ Micro 62(11): 4280-4283.

[16]. Morand-Fehr P (1989) Influence of environment on mortality of kids. Colloq Inst Natl Rech Agron 28: 31-46.

[17]. Muller LD, Syhre DR (1975) Influence of chemicals and bacterial cultures on preservation of colostrum. J Dairy Sci 58(6): 957-961.

[18]. Ramírez A, Quiles A, Hevia ML, Ramírez MC (1996) Influence of forced contact on the maternal-filial bond in the domestic goat after different periods of post-partum separation. Small Rumin Res 23(2): 75-81.

[19]. Skrivanova V, Skrivan M, Dobsinsky O (1984) Frozen colostrum as a source of immunoglobulins for calves in the first days of life. Zivocisna Vyroba 29: 131-136.

[20]. Steinbach G, Kreutzer B, Meyer H (1981) Zum einfluss der erwarmung auf den immunbiologischen wert des rinderkolostrums. Monatshefte Veterinarmedizin 36: 29-31.

[21]. Tyler JW, Lakritz J, Hostetler DE, Douglas V, Weaver DM, et al. (2000) Effect of pasteurization at 76 and $63^{\circ} \mathrm{C}$ on the absorption of colostral IgG in calves. J Dairy Res 67(4): 619-623.

[22]. Valenta J (1982) Short term preserved colostrum in the rearing of calves. Veterinarstvi 32: 410-411. 